Egyptian Journal of Rabbit Science, 25(1): 83 - 101(2015)

\title{
ROLE OF EARLY NEONATAL HEAT ACCLIMATION IN ALLEVIATE HYPERTHERMIA-INDUCED OXIDATIVE STRESS IN RABBITS
}

\author{
A. S. O. EI-Badry; Fadila, M. Easa; Ayat A. Ragab.; Amal M. Hekal; \\ Kh. A. A. Ali and F. B. A. Badri* \\ Department of Rabbit Breeding Research, Animal Prod. Res. Inst., Agric. \\ Res. Center, Ministry of Agric., Dokki, Giza, Egypt \\ *Poultry Production Department, Faculty of Agriculture, Ain Shams \\ University, Cairo, Egypt.
}

The objective of this study was to determine role of early thermal conditioning in reducing adverse effects of heat stress during summer season. Sixty New Zealand White (NZW) kits were divided into three groups (20 kits/group). The first group was kept under normal ambient temperature $\left(25 \pm 3^{\circ} \mathrm{C}\right)$ as control group. The second and third groups were exposed to high ambient temperature $\left(36 \pm 3^{\circ} \mathrm{C}\right)$ at day 3 and 10 post-partum for $1 \mathrm{~h}$ for 3 consecutive days by using electric heaters, respectively. All kits were weaned at 28 days of age.

The heat shock protein 70 (HSP70), acetylcholinesterase enzyme activity, body temperature, serum transaminases enzymes, glucose, lactate dehydrogenase enzyme, total protein, albumin, reduced glutathione, thiobarbituric acid-reactive substances, superoxide dismutase and catalase were assessed. Also, total lipid, cholesterol, triglyceride, high density lipoprotein and low density lipoprotein were assayed. Summer season was found to elicit significant deterioration in all the tested parameters confirming its impact, and season caused significant decrease in the activity of serum and brain cholinesterase but the rate of Hsp70 expression was less compared to the heat acclimated groups.

Conclusively, kit rabbits subjected to thermal conditioning at early age have the ability to cope with heat stress during the summer, which indicates the protective role of early age thermal conditioning.

Keywords: Early neonatal, heat acclimation, alleviate hyperthermia, induced oxidative stress, rabbits 
Homeostasis is constantly challenged by intrinsic and extrinsic adverse stressors. Excessive levels of reactive oxygen species (ROS) can be stimulated by stressful and clinical conditions (Droge, 2002) and result in the disturbance of balance between the oxidative and antioxidant defense systems, causing lipids peroixdation (LPO) and oxidative damages to proteins and DNA (Droge, 2002). Erythrocytes are particularly sensitive to oxidative damage due to the presence of high polyunsaturated fatty acid content in their membranes and high cellular concentrations of oxygen and haemoglobin (Hgb) (Mansour and Mossa, 2009). In mammals, heat stress can enhance the formation of ROS and induce oxidative stress in cells (Lordfontaine and Averill-Bates, 2002).

Heat acclimation is an evolutionarily conserved feature leading to the generation of metabolically efficient, thermotolerant phenotype. The acclimation process is biphasic, the initial, transient phase is characterized by impaired cellular processes and increased excitability of the autonomic nervous system compensates for impaired cellular processes in order to achieve thermoregulation. Efficient metabolic and molecular processes replace the need for enhanced autonomic excitability. The development of acclimatory homeostasis depends on a continuum of temperature adaptive shifts in gene expression (HSPs) during the entire acclimation regimen; however, during the initial acclimation phase (2-5 days), the transcriptional program of acclimation is activated. Important changes occur in the expression pattern of stress-associated genes including those responsible for the heat shock response and anti-oxidative networks (Miri et al., 2010). Induction of Hsp expression appears to correlate with a cytoprotective effect in cultured cells and with improved healing of damaged tissues in rabbits (Tan et al., 1997).

Acetylcholinesterase (AchE) in erythrocytes is one of the typical extraneural AChE enzymes. AchE has an essential role in acetylcholinemediated neurotransmission. It is present in the cholinergic synapses in the central nervous system as well as in neuromuscular synapses where it rapidly hydrolyzes acetylcholine (Marina et al., 2012). The acetylcholine (Ach) plays an important role as a neuromodulator in the brain, despite its role as the primary excitatory neurotransmitter in the periphery. The role of Ach in control of autonomic functions is well known, but it is likely that actions of Ach in the brain also modulate adaptive responses to environmental and metabolic conditions. Cholinergic signaling can alter thermoregulation (Myers and Waller, 1973) and endocrine functions (Ishikawa et al., 1982). 
In rabbits, the neonatal period is a critical time of development, and subsequent health and performance can be manipulated through changes in the neonatal thermal environment (Olexiková et al., 2007). This is mainly because the neonatal rabbit's thermoregulatory system at birth is not fully mature. Cooper et al., (1980) reported that thermal stimulation during the first 14 days of life rabbits could be of major importance to the development of the thermoregulatory system.

Therefore, the aim of the present study was to determine effect of early thermal acclimation on central thermoregulatory mechanisms of postnatal rabbits by acetylcholinesterase activity and heat shock proteins during summer season.

\section{MATERIALS AND METHODS}

\section{Animals and experimental design}

This study was carried out at the Rabbits Farm of Sakha Station, Animal Production Research Institute, Agriculture Research Center, Egypt.

Sixty New Zealand White (NZW) rabbit kits were divided into three groups (20 kits /group). The first group was kept under normal ambient temperature $\left(25 \pm 3^{\circ} \mathrm{C}\right)$ as control group. The second and $3^{\text {rd }}$ groups were exposed to high ambient temperature $\left(36 \pm 3^{\circ} \mathrm{C}\right)$ at day 3 and 10 post-partum for $1 \mathrm{~h}$ for 3 consecutive days by using electric heaters, respectively.

All kits in both groups were weaned at days 28 of age. After weaning, rabbits were individually housed in galvanized wire cages provided with feeders and automatic stainless steel nipple drinkers where basal diet and water were offered ad libitum.

The work lasted for 10 weeks in summer season (June to August, 2013), where the environmental temperature ranged between $25.6{ }^{\circ} \mathrm{C}$ to 36.5 ${ }^{\circ} \mathrm{C}$ while, humidity was from 45.5 to $70.5 \%$. Rabbits were reared under the same managerial and hygienic conditions as well as fed basal diet contained $2460 \mathrm{ME}$ kcal, $15 \% \mathrm{CP}, 11.17 \% \mathrm{CF}$.

\section{Studied parameters:}

\section{Thermoregulatory parameters}

Rectal temperature was measured individually at midday by a digital thermometer. The tip of thermometer was inserted to a depth of approximately $4 \mathrm{~cm}$ into the rectum and Tr was measured with an accuracy of $\pm 0.1^{\circ} \mathrm{C}$. Respiration rate was measured by visually counting breaths per minute using a stop watch and were done when the animal was sitting quietly 
and breathing regularly at 8.00 a.m. These measurements were recorded at the $10^{\text {th }}$ week of age.

\section{Estimation of heat shock proteins 70 (HSP70):}

HSP70 levels of brain were measured by using the enzyme-linked immunosorbent assay (ELISA) Kit of R\&D Systems (DYC1663E, Minneapolis, MN, USA). The optical density was measured at $\lambda=490 \mathrm{~nm}$ (reference at $\lambda=620$ $\mathrm{nm})$. The detection range of the assay was $0.05-2000 \mathrm{ng} / \mathrm{ml}$.

\section{Biochemical parameters:}

Blood samples from each group were taken at the 10th week of age. Two samples were taken per animal; the first sample was collected into vials containing (EDTA) as an anticoagulant to determine erythrocyte counts. The second blood samples were centrifuged at $3500 \mathrm{rpm}$ for 20 minutes to obtain serum, serum samples were stored at $-20^{\circ} \mathrm{Cuntil}$ assayed.

The level of glucose was determined with kits from Biosystems, S.A. Costa Brava, 30-Barcelona (Spain). The activities of liver aspartate aminotransferase (AST; EC 2.6.1.1) and alanine aminotransferase (ALT; EC 2.6.1.2) were assayed by the kinetic methods of Bergmeyer et al. (1986). Determination of lactate dehydrogenase (LDH; EC 1.1.1.27) activity was carried out using kits from Sentinel CH. (via principle Eugenio 5-20155 Milan-Italy). Serum concentrations of total lipid and cholesterol were assayed by the method of Knight et al. (1972) and Carr et al. (1993), respectively. High density lipoprotein (HDL) and low density lipoprotein (LDL) were determined according to the methods of Warnick et al. (1983) and Bergmenyer (1985), respectively. The protein content was determined by the method of Lowry et al. (1951) using bovine serum albumin as a standard. Acetyl cholinesterase (AchE; EC 3.1.1.7) activity was measured in brain and serum according to the method of Blawen et al. (1983).

\section{Oxidative and antioxidive status:}

The extent of lipid peroxidation in terms of thiobarbituric acid reactive substances (TBARS) formation was measured according to the method of Esterbauer and Cheeseman (1990). Tissue homogenate was mixed with $1 \mathrm{ml}$ trichloroacetic acid (TCA) (20\%), $2 \mathrm{ml}$ thiobarbituric acid (TBA) (0.67\%) and heated for $1 \mathrm{~h}$ at $100^{\circ} \mathrm{C}$. After cooling, the precipitate was removed by centrifugation. The absorbance of the sample was measured at $535 \mathrm{~nm}$ using a blank containing all the reagents except the sample. Glutathione content (GSH) was determined using commercial glutathione reduced kits (Biodiagnostic for diagnostic reagents: Dokki, Giza, Egypt) according to the 
method of Beutler et al. (1963). The catalase (CAT) activity was measured spectrophotometrically at $240 \mathrm{~nm}$ by calculating the rate of degradation of $\mathrm{H}_{2} \mathrm{O}_{2}$; the substrate of the enzyme (Xu et al., 1997). Super oxide dismutase (SOD; EC 1.15.1.1) was assayed according to Misra and Fridovich (1972).

The assay procedure involves the inhibition of epinephrine autooxidation in an alkaline medium ( $\mathrm{pH}$ 10.2) to adrenochrome, which is markedly inhibited by the presence of SOD. Epinephrine was added to the assay mixture that contains the tissue supernatant. The change in extinction coefficient was followed at $480 \mathrm{~nm}$ in a Spectrophotometer.

\section{Statistical analysis}

All results were analyzed using the general linear models procedure of SAS (1999). The model was:

$$
\mathrm{Yij}=\mu+\mathrm{Gi}+\mathrm{eij}
$$

Where: $\mu=$ the overall mean; $\mathrm{Gi}=$ effects of heat treatment and eij $=$ residual error term. Duncan's multiple range tests was performed (Duncan, 1955) to detect significant differences among means.

\section{RESULTS AND DISCUSION}

\section{Changes in AcetylCholinestrase (AchE) Activity and HSP70}

Acetylcholinesterase activities have been found to increase with age in the developing brain of rabbit. It was reported that changes in acetylcholine content could be produced by change of temperature (Aly et al., 1986).

Summer season caused significant decrease in the activity of serum and brain AchE in control group compared to the heat acclimated groups as shown in Table 1. On contrast, the specific activity of AchE in the serum and brain extract could be normalized by treatment with heat acclimation. These results are in agreement with Aly et al. (1986) who found that heat stress provoked a decrease in the AchE activity of the cerebrum region of the gerbil (Gerbillus pyramidum). Contrary to these observations, Menon and Dandiya (1969) reported that the activity of AchE was significantly increased in the brain of rats kept at high ambient temperature $\left(40^{\circ} \mathrm{C}\right)$. So, the heat stress may cause the disturbance in the cholinergic functions. These changes may in turn cause impairment in the development of neurons, oligodendrocytes and the tissues of the CNS (Rao et al., 1990).

Heat stress generally elicit their effects by inhibition of acetyl cholinesterase, which lead to accumulation of the neurotransmitter 
Table 1. Effect of early thermal acclimation in rabbits on Cholinestrase (chE) Activity and level of Heat Shock Proteins70 (HSP70) at 10 weeks of age during summer season.

\begin{tabular}{|c|c|c|c|c|}
\hline Traits & $\mathbf{C}$ & T1 & $\mathbf{T 2}$ & SE \\
\hline $\operatorname{chE}(\mathrm{U} / \mathrm{l})$ in serum & $75.91 \mathrm{a}$ & $56.31 \mathrm{~b}$ & $53.33 b$ & \pm 12.05 \\
\hline $\begin{array}{l}\text { chE (moles of substrate } \\
\text { hydrolysed/min/gm tissue) in brain }\end{array}$ & $37.69 a$ & $20.28 b$ & $22.44 b$ & \pm 1.84 \\
\hline HSP70 ng/ml & $0.77 \mathrm{c}$ & $3.53 \mathrm{a}$ & $2.90 \mathrm{~b}$ & \pm 0.21 \\
\hline
\end{tabular}

Table 2. Effect of early thermal acclimation in rabbits on thermoregulatory parameters at 10 weeks of age during summer season.

\begin{tabular}{lcccc}
\hline Traits & C & T1 & T2 & SE \\
\hline Rectal temperature ${ }^{\circ} \mathrm{C}$ & $39.88 \mathrm{a}$ & $38.22 \mathrm{~b}$ & $38.31 \mathrm{~b}$ & \pm 0.85 \\
Respiration rate $(\mathrm{rpm})$ & $112 \mathrm{a}$ & $81.40 \mathrm{~b}$ & $90.13 \mathrm{ab}$ & \pm 10.11 \\
\hline 2a, b.... Means with different superscripts within column are significantly different $(\mathrm{P} \leq 0.05)$.
\end{tabular}

acetylcholine in synapses; in the neuromuscular junction, over stimulation of postsynaptic cholinergic receptors leads to muscle fasciculation and eventual paralysis (Sharma et al., 1997). On the other hand, acetylcholinestrase inhibition elicits cholinergic stimulation in the central nervous system and in peripheral tissues and organs, which lead to marked dysfunction of homeostatic system, including temperature regulation (Gordon, 1996).

In the present study there was a very significant rise in AchE in the brain of control group. This rise in enzyme level leads to rapid cleavage of acetylcholine and thereby reduces concentration and turnover of Ach. A significant inhibition of AchE activity has been found in the rabbits treated with heat acclimation. Thus, the heat acclimation led to inhibit the rise in AchE activity.

The erythrocyte AchE activity was markedly reduced summer season. AchE in blood cells is biochemically identical to the enzyme contained in neurons and reveals low individual dispersion as well as high resistance towards external factors. Erythrocyte AchE plays an important role in the preservation of the integrity of the red cell. 


\section{HSP70 protein}

The expression of HSP70 protein was basically higher in the brain of heat acclimated groups than control group during summer season as shown in Table 1. Also, the intensity of the HSP70 protein expression was significantly increased in early heat acclimated at day 3 post-partum followed by heat acclimated at day 10 post-partum compared to control group. These results are agreed with Yamada et al. (2007) showed that after 10 days of heat acclimation the baseline levels of Hsp70 increased. The increase in Hsp70 has been associated with enhanced thermotolerance in vivo (Maloyan et al., 1999). Therefore, augmented Hsp70 may play a role in heat acclimation at the cellular level, enhancing cell tolerance to subsequent heat insults.

This shows that Hsp's play a role in physiological adaptation processes in stress situation (Kilgore et al., 1998). It is generally accepted that many Hsps provide cells with a mechanism to prevent damage caused by misfolded, damaged, aggregated proteins (Seok et al., 2007). One of these mechanisms is the stabilization of the intracellular protein structure, and Wang et al. (1996) demonstrate that elevated Hsp70 concentrations are closely related to slower rates of ATP depletion. A high brain expression of Hsp70 may account for the reduced disruption of cytoskeleton by oxidative stress (Kelly, 2005). It has been demonstrated that increased expression of Hsp70 protects in the brain and erythrocytes. This may indicate that the damage caused by the heat stress is higher than the rate of Hsp expression in control group. The phenomenon, acquired thermotolerance, has been associated with the accumulation of HSP induced by a short exposure to a nonlethal heat treatment. (Li et al., 1995). Therefore, assessing adaptation to training or to heat conditions may be monitored by the cell's content of HSP70, which may function as a cellular thermometer and a marker of recent thermal stress (Craig and Gross, 1991).

\section{Rectal temperature $(\mathrm{R} t)$ and Respiration rate $(\mathrm{Rr})$ :}

Data presented in Table (2), show significant differences in rectal temperature $\left({ }^{\circ} \mathrm{C}\right)$ and respiration rate in the experimental groups. At 10 weeks of age, the RT of HA1 and HA2 were significantly $(\mathrm{P} \leq 0.05)$ decreased than those of $\mathrm{C}$. It is well known that, adult rabbits are homeothermic and provided with physiological mechanisms by which they can maintain their deep body temperature constant within the thermoneutral zone. The increase in rectal temperature of the heat-stressed rabbits may be due to failure of the physiological mechanism (Marai et al., 2001). Also, the lower metabolic rate 
of heat-acclimated rabbits exposed to heat probably played an important role in preventing increased rectal temperatures (Oliveira et al., 1985).

The increase in respiration frequency is linearly related to the increase in ambient temperature and thus enables the animals to dissipate heat. Frangiadaki et al., (2003) found that rectal temperature of rabbits and respiration rate were high in the hot period $\left(39.09^{\circ} \mathrm{C}\right.$ vs $38.93^{\circ} \mathrm{C} ; 128.08$ respiration/min vs 115.37 respiration's/min).

On the other hand, instantaneous increase in body temperature by exposing the subjects in acute environmental heat induces the synchronization of neuronal firing of the brain to control heat production in animal body through secretion of some neurotransmitters (Giocomo and Hasselmo, 2000). Thus, skin vasodilation and sweating are initiated at a lower core temperature threshold, and higher sweat rates can be sustained without the sweat glands becoming "fatigued" and skin vascular responses to acetylcholine administration were improved by heat acclimation. The data indicate that activation of the cholinergic receptors within brain with methacholine decreases heat production and/or increases heat loss which, leads to hypothermia in rats Lin et al., (1979).

\section{Blood parameters and erythrocyte counts:}

The effect of heat acclimation on the levels of serum biochemical parameters is summarized in Table 3. Results from this study shows that summer season caused malfunction of liver. This effect was indicated in part through highly significant increases in the levels of serum transaminases (ALT and AST). Concurrent with this result, significant elevations in the activity of lactate dehydrogenase (LDH) and the level of glucose, respectively were recorded in the same group when compared to the heatacclimated groups. This agrees with the low lactate dehydrogenase activities in the liver extract of rats in the acclimated group in the previous findings of Janet et al., (1975). LDH was found to be an indicator of anemia, renal stress, muscular dystrophy as well as liver damage (Kachmar and Moss, 1976). An increase in LDH indicates the deterioration of different tissues suffering from heat stress during the summer season. The increase in the activities of ALT, AST and LDH in serum is mainly due to the leakage of these enzymes from the liver cytosol into the blood stream, which reflects disruption of normal 
ROLE OF EARLY NEONATAL HEAT ACCLIMATION IN ALLEVIATE IN RABBITS 91

Table 3. Effect of early thermal acclimation in rabbits on serum biochemical parameters at 10 weeks of age during summer season.

\begin{tabular}{lcccc}
\hline Traits & $\mathbf{C}$ & T1 & T2 & SE \\
\hline Glucose mg/dl & $131.63 \mathrm{a}$ & $67.48 \mathrm{~b}$ & $82.19 \mathrm{~b}$ & \pm 12.05 \\
AST U/l & $41.36 \mathrm{a}$ & $31.66 \mathrm{~b}$ & $32.71 \mathrm{~b}$ & \pm 3.47 \\
ALT U/l & $38.11 \mathrm{a}$ & $21.97 \mathrm{~b}$ & $28.11 \mathrm{ab}$ & \pm 3.01 \\
LDH U/1 & $1205.9 \mathrm{a}$ & $700.1 \mathrm{~b}$ & $719.2 \mathrm{~b}$ & \pm 333.21 \\
Total protein g/L & $4.79 \mathrm{~b}$ & $6.47 \mathrm{a}$ & $6.79 \mathrm{a}$ & \pm 0.53 \\
Albumin g/L & $3.08 \mathrm{~b}$ & $3.46 \mathrm{a}$ & $3.47 \mathrm{a}$ & \pm 0.08 \\
\hline II Data expressed as LSM \pm S.E & \multicolumn{3}{|}{} \\
2a, b... Means with different superscripts within column are significantly different $(\mathrm{P} \leq 0.05)$.
\end{tabular}

liver function (Shakoori et al., 1988). Also, the elevation in the activity of LDH suggests an increase in lysosomal mobilization and liver malfunction due to heat stress (Gupta, 2013).

The decrease in serum glucose could be due to the marked dilution of blood and body fluids as a whole or to the increase in glucose utilization to produce more energy for greater muscular expenditure required for high respiratory activity (Habeeb et al., 1993). Other studies showed that glucose concentration increases under heat stress conditions due to the decrease in glucose utilization, depression of both catabolic and anabolic enzyme secretions and subsequent reduction of metabolic rate (Webster, 1976).

The functional damage caused by heat stress was indicated by the significant decrease in the serum total protein and albumin concentrations compared to the heat-acclimated groups (Table 3). Shido et al. (1993) reported that the plasma levels of thyroid hormones, especially $\mathrm{T}_{3}$ increased during the period when the rats had been previously exposed to heat this increasing led to improve in blood metabolites. Normally, the reduction of serum proteins and albumin levels as shown in Table 3 indicates a liver malfunction. This reduction could be attributed to the changes in the metabolism and the synthesis of the protein and free amino acid in the liver (Li et al., 2007). Additionally, exposure of rabbits to heat acclimation conditions resulted in serum hyperalbuminemia indicating an adjustable mechanism to maintain blood volume by inducing water movement into the vascular system (Alamer, 2006). This finding is quite relevant since albumin is the major extracellular source of protein thiol groups. Thereby, inducing hyperalbuminemia permitted the utilization of albumin as an antioxidant to 
scavenge reactive oxygen species which may be produced from the exposure to heat stress during summer season (Ganaie et al., 2013).

Table 4 shows the lipids profile of all the studied groups in this study. The results shows that the summer season induced significant increases in the serum total lipids, total cholesterol, triglycerides and LDL while HDL was slightly increased compared to the heat acclimated groups. On the other hand, treatment with heat acclimation showed amelioration in the levels of serum total lipids, total cholesterol, triglycerides, LDL and HDL. These results are in concordance with those of Salem et al. (1998) who reported that plasma cholesterol concentrations were significantly higher during the summer compared to the winter, which could reflect total lipid content in the heatstressed rabbits. The increase in the level of serum cholesterol may be due to an increased synthesis of cholesterol in the liver (Enan et al., 1987). Also, the increase in serum total cholesterol level may be attributed to the blockage of liver bile ducts causing reduction or cessation of its secretion to the duodenum (Aldana et al., 1998). However, some studies have reported falls in cholesterol concentrations due to increases in total body water resulting from exposure to elevated environmental temperature (Habeeb et al., 1996). This elevation of serum or plasma triglycerides has been attributed to an inhibition of the lipase enzyme activity of both the hepatic triglycerides and plasma lipoproteins (Goldberg et al., 1982). HDL is mainly synthesized in the liver and intestinal cells. It plays an important role in cholesterol efflux from tissues and carries it back to the liver for removal as bile acids (Shakoori et al., 1988).

Table 4 showed significant decreases in RBC of the heat-stressed group compared to the heat acclimated groups. These results are in agreement with the findings of Seley (1960) who reported that heat stress in mammals decreased the level of ACTH, which might then result in decreases in RBC counts and $\mathrm{Hb}$ concentration. This drop in RBS is responsive trial to reduce oxygen intake, thus reducing metabolic heat production under this hot condition (Ashour, 2001). The decreases in oxygen intake are important for animals to keep heat balance (Solouma, 1999).

\section{Oxidative stress profile}

The results of the reduced glutathione content are represented in Table 5. It is clear that, the level of reduced GSH in the serum was greatly depleted by heat stress compared to the heat acclimated groups. In contrast, the level of TBARS was greatly elevated in heat stressed group compared to the heat 
Table 4. Effect of early thermal acclimation in rabbits on serum lipids profile and erythrocyte counts (RBC's) at 10 weeks of age during summer season.

\begin{tabular}{|c|c|c|c|c|}
\hline Traits & $\mathbf{C}$ & $\mathbf{T 1}$ & $\mathbf{T 2}$ & SE \\
\hline $\mathrm{RBC} \cdot \mathrm{s}\left(\times 10^{6} / \mathrm{mm}^{3}\right)$ & $5.33 b$ & $6.33 \mathrm{a}$ & $6.41 \mathrm{a}$ & \pm 0.84 \\
\hline Total lipids mg/dl & $538.77 \mathrm{a}$ & $393.86 b$ & $339.98 \mathrm{c}$ & \pm 13.78 \\
\hline Total cholesterol mg/dl & $114.53 \mathrm{a}$ & $74.53 b$ & $79.07 \mathrm{~b}$ & \pm 10.60 \\
\hline $\begin{array}{l}\text { Low density lipoprotein- } \\
\text { cholesterol mg/dl }\end{array}$ & $103.67 \mathrm{a}$ & $84.73 b$ & $86.29 b$ & \pm 9.84 \\
\hline $\begin{array}{l}\text { High density lipoprotein- } \\
\text { cholesterol mg/dl }\end{array}$ & 41.16 & 38.91 & 38.73 & \pm 0.7 \\
\hline Triglycerides mg/dl & $91.38 \mathrm{a}$ & $70.05 b$ & $70.87 \mathrm{~b}$ & \pm 38.33 \\
\hline
\end{tabular}

acclimated groups. The treatment with the heat acclimation could normalize the levels of reduced GSH and TBARS compared to the control group. Table 5 shows also that summer season caused significant reduction in the specific activities of catalase and superoxide dismutase compared to the heat acclimated groups. On contrast, the specific activities of serum catalase and superoxide dismutase could be normalized by treatment with heat acclimation. This result is consistent with findings of Abdel-Kafy et al. (2008), who reported that heat conditioning decreased the production of nitric oxide and increasing total antioxidant capacity.

Generation of oxidative stress and consequent lipid peroxidation by heat stress during summer season may be due to the high concentration of polyunsaturated fatty acids in cells, lipid peroxidation is a major outcome of the free radical-mediated injury (Surekha et al., 2008).

Heat stress during summer season has been shown to impair antioxidant enzyme activities either directly or through the induction of free radicals resulting in oxidative stress (Surekha et al., 2008). Our results show also that summer season to rabbits caused an increase in the lipid peroxidation, as evidenced by elevated level of TBARS and the decreased level of GSH (Table 5). These findings agree with the results obtained in a previous study (Surekha et al., 2008). They reported that tissue lipid peroxidation is a degradative phenomenon as a consequence of free radical chain production 
Table 5. Effect of early thermal acclimation in rabbits on Oxidative stress profile at 10 weeks of age during summer season.

\begin{tabular}{|c|c|c|c|c|}
\hline Traits & $\mathbf{C}$ & T1 & $\mathbf{T 2}$ & SE \\
\hline GSH (mg/dL) & $17.66 \mathrm{~b}$ & $38.31 \mathrm{a}$ & $37.66 \mathrm{a}$ & \pm 2.31 \\
\hline TBARS (mg/dL) & $1.97 \mathrm{a}$ & $0.36 \mathrm{~b}$ & $0.51 \mathrm{~b}$ & \pm 0.10 \\
\hline $\mathrm{SOD}(\mathrm{U} / \mathrm{mL})$ & $1.96 \mathrm{~b}$ & $2.91 \mathrm{a}$ & $2.47 \mathrm{ab}$ & \pm 0.19 \\
\hline CAT (U/mL) & $31.94 b$ & $48.11 \mathrm{a}$ & $48.07 \mathrm{a}$ & \pm 6.55 \\
\hline
\end{tabular}

and propagation which affects mainly polyunsaturated fatty acids. Lipid peroxidation has been used as a measure of this xenobiotic-induced oxidative stress, which was originally defined as the disequilibrium between prooxidants and antioxidants in the biological systems (Bebe and Panemangalore, 2003).

Mammalian cells are equipped with both enzymatic and non-enzymatic antioxidant defense mechanisms to minimize the cellular damage resulting from the interaction between cellular constituents and reactive oxygen species (ROS) (Goel et al., 2009). The enzymatic antioxidant defense mechanism contains various forms of superoxide dismutases, catalase and glutathione peroxi-dase. Despite of the presence of these delicate cellular antioxidant systems, an overproduction of ROS in both intra- and extracellular spaces often occurs upon exposure of cells or individuals to heat stress (Surekha et al., 2008).

It seems that temperature and humidity are the main factors in influencing the stress status. It can be said that the high polyunsaturated fatty acid content of erythrocyte membrane and the high iron content of haemoglobin in association with the high ambient temperature may have resulted in increased lipid peroxidation in heat stressed group of rats as reflected by the increase in erythrocyte TBARS in these rats (Surekha et al., 2008). They have found a lowered antioxidant defence status in erythrocytes of heat stressed group of rats as indicated by low levels of GSH and decreased activities of GSH-Px and SOD. One of the most important nonenzymatic protections against ROS-induced lipid peroxidation involves the glutathione pathway. Constant use of GSH as a result of lipid peroxidation results in a decrease in its levels. This is very well reflected in the heat 
stressed group of rats that show high erythrocyte TBARS and low erythrocyte glutathione levels. The lowering of GSH in erythrocytes has resulted in the associated decrease of GSHPx activity as reflected by the significant positive correlation between erythrocyte GSH and GSH-Px activity. High levels of glucocorticoids have been reported to decrease blood glutathione and erythrocyte superoxide dismutase activity in rats (Surekha et al., 2008). The increase in plasma cortisol in response to high ambient temperature could be an additional factor responsible for increasing the oxidative stress in the heat stressed group of rats as reflected by the decreased GSH level and SOD activity in their erythrocytes (Surekha et al., 2008).

Conclusively, symptoms of stress observed during summer season were much less in thermally-conditioned rabbits at day 3 post-partum followed by heat acclimated at day 11 post-partum as well as, HSP70 that may be essential for surviving and recovering from thermal injury, especially lipid oxidative damage.

The present study demonstrated some of the mechanisms involved in this adaptive response to heat stress. Further studies are needed to understand other mechanisms involved as well as the beneficial effects of cyclic conditioning of birds at early age.

\section{REFERENCES}

Abdel-Kafy, E.M.; Hoda, A.S. and Saeed, A. M. (2008). Changes in oxidative profile, activity of some gastrointestinal enzymes and performance of growing rabbits during hot season due to neonatal heat exposure. . 9th World Rabbit Congress - June 10-13, - Verona - Italy

Alamer, M., (2006). Physiological responses of Saudi Arabia indigenous goats to water deprivation. Small Rumin.Res., 63: 100-109.

Aldana, L.; De Mejía E.G., Craigmill A., Tsutsumi V., ArmendarizBorunda J., Panduro A. and Rincón A.R. (1998). Cypermethrin increases apo A-1 and apo BmRNA but not hyperlipidemia in rats. Toxicol. Lett., 95:31-39.

Aly, M.S.; M.I. ohamed; Abdel, T. Rahman and S. El Haggar, (1986). Regional acetylcholinesterase and monoamine oxidase in mammalian and avian brain. II. Temperature effects. Proc. Zool. Soc., 11: $87-101$.

Ashour, G. 2001. Physiological adaptation of rabbits' kits to housing conditions related to growth. Egypt. J. Rabbit Sci., Vol. 11:115-137 
Bebe FN, Panemangalore M (2003). Exposure to low doses of endosulfan and chlorpyrifos modifies endogenous antioxidants in tissues of rats. $J$. Environ. Sci. Health, Part B., 38:349-163.

Bergmenyer HU (1985). Methods of Enzymatic Analysis. 3rd ed., Vol. VIII:154-160.

Beutler E, Duron O, Kelly BM (1963). Improved method for the detection of blood glutathione. J. Lab. Clin. Med., 61:882-888.

Blawen DH, Poppe WA, Trischler W (1983). The effect of subacute doses of organophosphorus pesticide, nuvacron, on the biochemical and cytogenetic parameters of mice and their embryos. J. Clin. Chem. Biochem., 21:381-386.

Carr TP, Andressen CJ, Rudel LL (1993). Enzymatic determination of triglyceride, free cholesterol and total cholesterol in tissue lipid extracts. Clin. Biochem. , 26:39-42.

Cooper, K. E.; A. V. Ferguson* And W. L. Veale. (1980). Modification of thermoregulatory responses in rabbits reared at elevated environmental temperatures. J. Phygiol., 303:165-172.

Craig, E. A., Gross, C. A. (1991). Is hsp70 the cellular thermometer? Trends Biochem. Sci. ,16:135-140.

Duncan, D. B. 1955. Multiple range and multiple F tests. Biometrics,11:1-42

Droge, W. (2002). Free radicals in the physiology control of the cell function. Physiol. Rev.,82:47-95.

Enan E, Berberian IG, El-fiky S, El-Masry M, Enan OH (1987). Effects of two organophosphorus insecticides on some biochemical constituent in the nervous system and liver of rabbits. J. Environ. Sci. Health, Part B. 22:149-170.

Esterbauer H, Cheeseman KH (1990). Determination of aldehydic lipid peroxidation products: malonaldehyde and 4-hydroxynonenal. Methods Enzymol., 186:407-421.

Frangiadaki E., Golidi E., Menegatos I., and Luzi F. (2003). Comparison of does' performances under high and moderate temperature in a greek commercial farm. World Rabbit Sci., 11: 137 - 143.

Ganaie, A.H., Shanker, G., Bumla, N.A., Ghasura, R.S., Mir, N.A., Wani, S.A. And Dudhatra, G.B., (2013). Biochemical and physiological changes during thermal stress in bovines. J. Vet. Sci. Techn., 4: 126-132.

Giocomo, L.M. and M.E. Hasselmo (2007). Neuromodulation by glutamate and acetylcholine can change circuit dynamics by regulating the relative influence of afferent input and excitatory feedback. Mol. Neurobiol., 36: 184-200. 
Goel M, Eraslan G, Silici S (2009). Antioxidant effect of propolis against exposure to propetamphos in rats. Ecotoxicol. Environ. Safety, 72:900-915.

Goldberg IJ, Le NA, Paterniti JR, Ginsberg HN, Lindgren FT, Brown WV (1982). Lipoprotein metabolism during acute inhibition of hepatic triglyceride lipase in the Cynomolgus monkey. J. Clin. Invest., 70 (6):1184-1192.

Gordon, C.J., (1996). Thermoregulatory aspects of environmental exposure to anticholinesterase agents. Rev. Environ. Health, 11: 101-117.

Gupta, Sudhanshu, Deepika.(2013). Assessment of liver damage in male albino rats after repetitive heat stress of moderate level. Nat.l J. Physiol. Pharmacol., 3(2): 147-152.

Habeeb A.A., Aboul-Naga A.I. and Yousef H.M. (1993). Influence of exposure male growing Californian rabbits. to high temperature on daily gain, feed efficiency and blood components. Egyptian Journal Rabbit Science, 3: 73-80.

Habeeb AAM, El-Masry KA, Aboulnaga AI, Kamal TH (1996). The effect of hot summer climate and level of milk yield on blood biochemistry and circulating thyroid and progesterone hormones in Friesian cows. Arab Journal of Nuclear Sciences and Applications, 29: 161-173.

Ishikawa, M. Suzuki, T. Shimazu (1982). Effects of acetylcholine injection into the hypothalamus on the insulin and glucagon release. Neuroendocrinology, 34 (1982), pp. 310-314.

Janet S. Kerr, Robert L. Squibb and Harry M. Frankel (1975). Effect of heat acclimation $\left(32^{\circ} \mathrm{c}\right)$ on rat liver and brain substrate levels. International Journal of Biochemistry, Volume 6, Issue 3, Pages 191-195

Kachmar, J. F. and Moss, D. W. (1976). Enzymes. In: Tietz, N. W., "Fundamentals of Clinical Chemistry "Philadelphia, USA. : W. B. Sanders Company, pp 653-654.

Kelly, K.J., (2005). Heat shock (stress response) proteins and renal ischemia/reperfusion injury. Contrib. Nephrol., 148: 86-106.

Knight JA, Anderson S, Rawle JM (1972). Chemical basis of the sulfophosphovanillin reaction estimating total serum lipids. Clin. Chem. 18:199-202.

Li, G. C., Mivechi, N. F., Weitzel, G. (1995). Heat shock proteins, thermotolerance, and their relevance to clinical hyperthermia. Int. J. Hyperth., 11:459-488 
Li, Yu-bao, Bao, En-dong, Wang, Zhi-liang, Zhao, Ru-qian, (2007). Detection of HSP mRNA transcription in transport stressed pigs by fluorescence quantitative RT-PCR. Sci. Agri. Sini., 6: 361-367.

Lin, M. T.; F. F. Chen, Y. F. Chern, T. C. Fung (1979). The role of the cholinergic systems in the central control of thermoregulation in rats. Canadian Journal of Physiology and Pharmacology, 1979, 57(11): 12051212.

Lord-fontaine, S. and Averill-Bates, D. A. (2002). Heat shock inactivity cellular antioxidant defenses against hydrogen peroxide : protection by glucose. Free Radic. Biol. Med., 32: 752-765.

Lowry OH, Rosebrough NJ, Farr AL, Randall RJ (1951). Proteinmeasurement with the Folin phenol reagent. J. Biol. Chem., 193:265-275.

Maloyan, A., Palmon, A., Horowitz, M. (1999). Heat acclimation increases the basal HSP $72 \mathrm{kDa}$ level and alters its production dynamics during heat stress. Am. J. Physiolo., 276: R 1506-1515.

Mansour S, and Mossa A. (2009). Lipid peroxidation and oxidative stress in rat erythrocytes induced by chlorpyrifos and the protective effect of zinc. Pestic Biochem Physiol;97:34-39.

Marai, I.F.M. and M.S.Ayyat and U.M. Abd-El-Monem (2001). Growth performance and reproductive traits at first parity of New Zealand whit female rabbits as affected by heat stress and its alleviation under Egyptian conditions. Trop. Anim. Health Prod., 33: 451-462.

Marina, R. Picciotto;Michael J. Higley and Yann S. Mineur (2012). Acetylcholine as a Neuromodulator: Cholinergic Signaling Shapes Nervous System Function and Behavior. Volume 76, Issue 1, 4 October, Pages 116-129

Menon, M.K. and P.C. Dandiya, (1969). Behavioral and brain neurohumoral changes produced by acute heat stress in rats: Influence of psychopharmacological agents. Eur. J. Pharmacol., 8: 284-291.

Miri Assayag, Gary Gerstenblith, Michael D. Stern and Michal Horowitz (2010). Long-but not short-term heat acclimation produces an apoptosisresistant cardiac phenotype: a lesson from heat stress and ischemic/ reperfusion insults. Cell Stress Chaperones. Sep 2010; 15(5): 651-664.

Misra HP, Fridovich I (1972). The role of superoxide anion in the autoxidation of epinephrine and a simple assay for superoxide dismutase. J. Biol. Chem., 247:3170-3175. 
Myers, R.D. and M.B. Waller. (1973). Differential release of acetylcholine from the hypothalamus and mesencephalon of the monkey during regulation. J. Physiol., 230 (1973), pp. 273-293.

Oliveira SG, Tarasantchi J, Griggio MA. (1985). Effects of temperature acclimation on rabbit metabolic rate and rectal temperature. Braz J. Med. Biol. Res. ;18(3):367-72.

Olexiková, L.; A.V. Makarevič; P. Chrenek; E. Kubovičová; and J.PIVKO (2007). development of rabbit preimplantation embryos under thermal stress in vitro. Slovak J. Anim. Sci., 40 (2): 63 - 65.

Rao, G.S., V. Abraham, B.A. Fink, N. Margulies and M.C. Ziskin, (1990). Biochemical changes in the developing rat CNS due to hyperthermia. Teratology, 41: 327-332.

SAS (1999). SAS/STAT user's guide, Version 8. SAS Institute Inc., Cary, N.C., USA.

Salem, I.A.; Kobeisy, M.A.; Zenhom, M.; Hayder, M. (1998). Effect of season and ascorbic acid supplementation on some blood constituents of suckling Chios lambs and its crosses with Ossimi sheep in upper Egypt. Assiut Journal of Agriculture Science, 29: 87-100.

Seley H. (1960): The concept of stress in experimental physiology.In: Tanner YJM (eds.): Stress and Psychiatric Disorders.1st ed. Blackwell Scientific Publications, 67-75.

Seok, Y.M., Kim, J.N., Choi, K.C., Yoon, C.H., Boo, Y.C., Park, Y.K., Park, K.M., (2007). Wen-pi-tang-Hab-Wu-ling-san attenuates kidney ischemia/reperfusion injury in mice: a role for antioxidant enzymes and heat-shock proteins. J. Ethnopharmacol. 112: 333-340.

Shakoori, A.R.; Ali, S.S. and Saleem, M.A. (1988). Effects of six months feeding of cypermethrin on the blood and liver of albino rats. J. Biochem. Toxicol. ,3:59-72.

Sharma, H.S.; J. Westman; J. Cervos-Navaro and F. Nyberg (1997). Role of neurochemicals in brain edema and cell changes following yperthermic brain injury in the rat. Acta. Neurochir. Suppl., 70: 269-274.

Shido O, Sakurada S, Hashimoto T, Fujikake K, Nagasaka T.( 1993). Increase in plasma thyroid hormone levels during the previous heat exposure time in heat acclimated rats. Can J Physiol Pharmacol; 71(12): 904-909.

Solouma, G. M. (1999). Physiological Adaptive Response of Small Ruminants to Environmental Conditions. Ph D. Thesis., Fac. Agric., Cairo Univ., Giza, Egypt. 
Surekha Bhat, Guruprasad Rao, K Dilip Murthy and P Gopalakrishna Bhat. (2008). Seasonal variations in markers of stress and oxidative stress in rats. Indian Journal of Clinical Biochemistry, 2008 / 23 (2) 191-194.

Tan, M.; Hua, X and Qiu, R. (1997). Distribution of $70 \mathrm{Kda}$ heat shock protein in rabbit brains after heat stress and heat stroke. Zhonghua Bing Li Xue Za Zhi., 26 (1) : 38-40.

Wang, D., Mcmillin, J.B., Bick, R., Buja, L.M., (1996). Response of the neonatal rat cardiomyocyte in culture to energy depletion: effects of cytokines, nitric oxide, and heat shock proteins. Lab. Invest., 75: 809-818.

Warnick GR, Benderson JM, Albers JJ (1983). Selected methods Clin. Chem., 10:91-99.

Webster, A.J.F. (1976). The influence of the climatic environment on metabolism in cattle. In Principles of Cattle Production, edited by H. Swan and W.H. Broster. Butterworth, London.

Xu JB, Yuan XF, Lang PZ (1997). Determination of catalase activity and catalase inhibition by ultraviolet spectrophotometry. Chin. Environ. Chem., 16:73-76.

Yamada, P. M.; Amorim FT, Moseley P, Robergs R, Schneider SM.( 2007). Effect of heat acclimation on heat shock protein 72 and interleukin-10 in humans. J. Appl. Physiol.,103:1196-1204.

$$
\begin{aligned}
& \text { دور التأقم الحرارى المبكر للصغار فى تخفيف الاجهاد التأكسدي } \\
& \text { الناجم عن ارثفاع الحرارة في الأرازب } \\
& \text { عيدالعزيز سيد عثمان البدرى ـ فضيلة محمدعيسى ـ ايات رجب عبد المقصود ـ امل مغاورى إمي }
\end{aligned}
$$

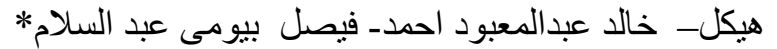

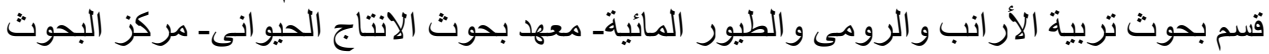

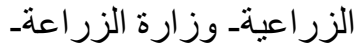

$$
\begin{aligned}
& \text { * قسم إنتاج الدو اجن، كلية الزراعة ، جامعة عين شمس، مصر. الزراعة. }
\end{aligned}
$$

كان الهدف من هذه الدراسة هو تقيم الآثار المفيدة للاقلمة الحرارية عند

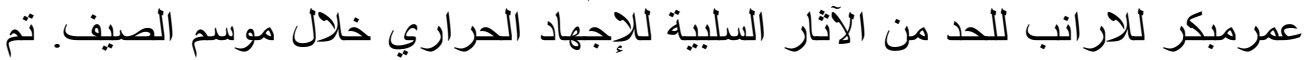

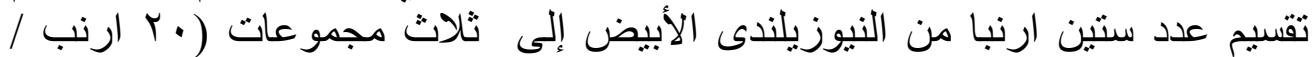
مجموعة). المجموعة الأولى ربيت تحت درجة الحرارة الطبيعية كمجموعة كنترول 
ROLE OF EARLY NEONATAL HEAT ACCLIMATION IN ALLEVIATE IN RABBITS 101

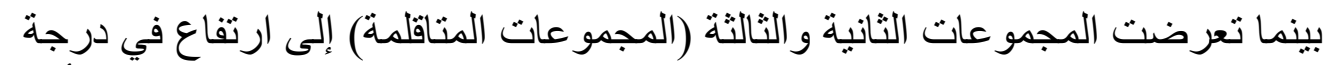

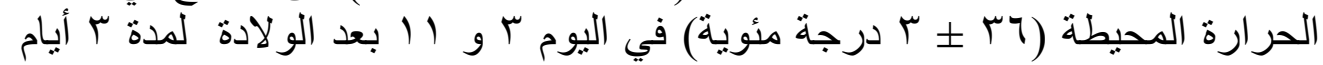

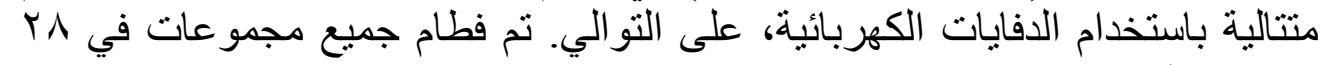
البروتينات الصدمة الحرارية و درجة حرارة الجسم (HSP70) نشاط انزيم

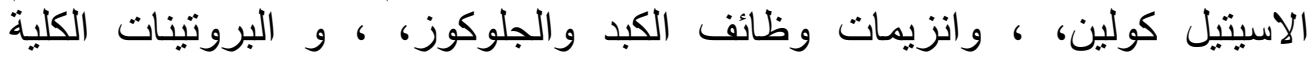

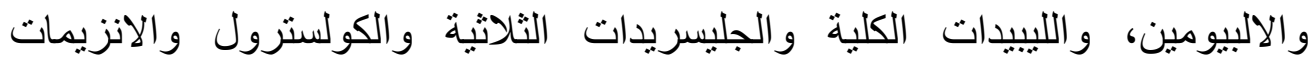
المضادةللاكسدة وكذلك البيروكسيدات.

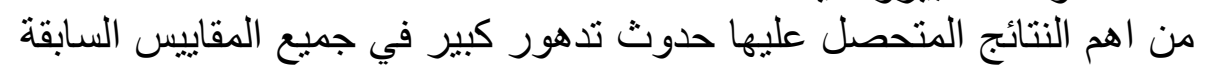

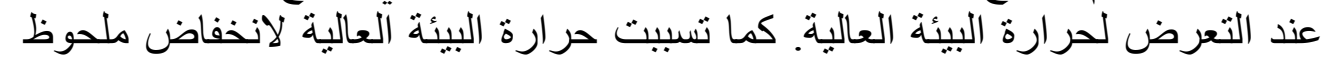

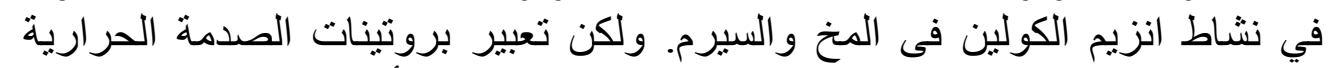

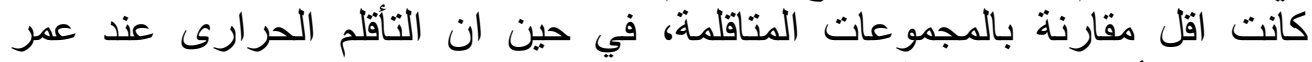

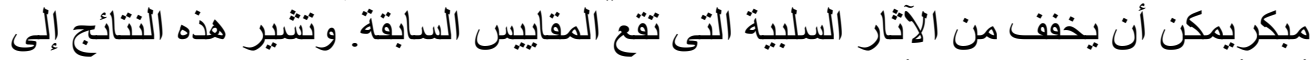

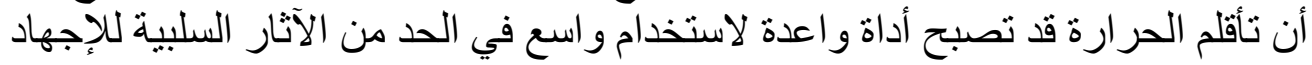

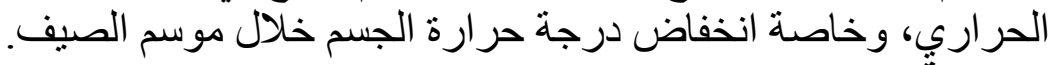
التوصية: تعرض صغار الار انب للحرارة عند سن مبكرتكون لها القدرة على موارة اجهة الإجهاد الحراري خلال فصل الصيف مما يدل على الدور الوقائي للتكييف الحرارية 